\title{
The Effectiveness of the Problem Solving Strategy and the Scientific Approach to Students' Mathematical Capabilities in High Order Thinking Skills
}

\author{
Hardi Tambunan ${ }^{1^{*}}$ \\ ${ }^{7}$ Department of Mathematics Education, Nommensen HKBP University, Medan, INDONESIA \\ *CORRESPONDENCE: $\$ tambunhardi@gmail.com
}

\begin{abstract}
The purpose of this study was to find out more effective teaching among problem solving strategy with a scientific approach to students' mathematical abilities in high order thinking skills. This quasi experimental study used non-equivalent pretest-posttest control group design. The experimental group was students who were taught with problem solving strategy, and the control group was students who were taught with the scientific approach. The number of participants for the experimental group, $n=138$, and for the control group, $n=139$ from the $10^{\text {th }}$ grade of public and private high schools in Medan-Indonesia. Based on the hypothesis testing of the study, the results showed that learning through problem solving strategy was more effective than the scientific approach to students' mathematical abilities in communication, creativity, problem solving, and mathematical reasoning.
\end{abstract}

Keywords: mathematics education, problem solving, scientific approach, HOTS

\section{INTRODUCTION}

Problem solving is still an important issue in school mathematics education. This has been stated by teachers who have joined the national council of teachers of mathematics (NCTM) since the 1980s, and advocated problem solving must be the focus of school mathematics (Sobel \& Maletsky, 1988). Problem solving has been one of the general goals overall in the finish curriculum (Pehkonen, 2007). The problem solving is the important part of the mathematics curriculum, because students can use the skills they already have to apply to solving the problem (Posmentier \& Krulik, 2009). Solving math problems as an important aspect, and becoming a necessity in a mathematics curriculum throughout the world (Liljedah, Trigo \& Malaspina, 2016). Problem solving plays an important role in mathematics education so that students can practice and integrate the concepts, theorems and skills that have been learned (Hudojo, 2005), students get good, diligent, high desire, and confident ways of thinking (Turmudi, 2008), and improve students' mathematical abilities (NCTM, 2010). Another opinion states that problem solving as the heart in learning mathematics, and all creative mathematical activities require problem solving actions (Pinta, Tayruakham \& Nuangchalerm, 2009; Yazgan, 2015), can improve students' imagination (Wibowo, et al., 2017), to develop student creativity (Suastika, 2017), and can support students' understanding skills (Mulyadi, 2017).

Problem solving in school mathematics education in Indonesia has actually begun to be adapted in the mathematics curriculum in 2006. However, learning begins with problems, starting in the 2013 mathematics curriculum, and implementation is emphasized through a scientific approach with the aim that students have the attitudes, knowledge and skills elaborated for each education unit (Permendikbud (54), 2013). The

Article History: Received 28 December $2018 \bullet$ Revised 8 January $2019 \bullet$ Accepted 26 January 2019

(C) 2019 by the authors; licensee Modestum Ltd., UK. Open Access terms of the Creative Commons Attribution 4.0 International License (http://creativecommons.org/licenses/by/4.0/) apply. The license permits unrestricted use, distribution, and reproduction in any medium, on the condition that users give exact credit to the original author(s) and the source, provide a link to the Creative Commons license, and indicate if they made any changes. 
expected learning outcomes for aspects of knowledge and skills refer to the PISA standard, namely high order thinking skills (HOTS)(Effendy, 2018). The importance of high order thinking skills in mathematics education is so that students can master mathematics well (Amalia, 2013). There is a significant relationship between high order thinking skills and student learning outcomes in every aspect (Abdullah, et al, 2017; Jailani, Sugiman \& Apino, 2017; Tanujaya, Mumu \& Margono, 2017; Widodo \& Kadarwati, 2013).

Many factors can influence the achievement of HOTS, such as internal and external factors. Internal factors, namely the interests and motivation of students in learning mathematics (Lazarides \& Ittel, 2012; Sukada, 2013; Maurice, Dorfler \& Artelt, 2014; Sumantri \& Whardani, 2017; Surifah, 2016; Tambunan, 2018). Viewed from external factors, namely the use of approaches and implementation of learning (Al-Agili, 2012; Justice, Agyman \& Nkum, 2015; Margaret, 2015; Sa'ad, 2014), and suitability test questions with the ability students (Tambunan, 2016; 2018). Some approaches that can be used in learning, so that the achievement of HOTS students in mathematics can be achieved well, including the strategy to solve problems developed by Polya (1973), and scientific approaches (Permendikbud (81A), 2013).

\section{PROBLEM SOLVING STRATEGY}

Several stages of problem solving methods, Polya (1973) state four stages, namely (1) understand the problem, (2) devise a plan, (3) carry out the plan, and (4) look back. The indicators, namely (1) identify the elements that are known, asked, and the required elements are needed; (2) formulating mathematical problems or compiling mathematical models; (3) applying strategies to solve problems or mathematical models; (4) explain or interpret the results according to the original problem; (5) use mathematics meaningfully (NCTM, 1989).

In mathematics learning, using problem solving strategies has an impact on students' abilities and skills. The results of the study show that the problem solving approach affects the ability and academic achievement of students (Ali, Hukamdad, Akhter \& Khan, 2010; Perveen, 2010; Sriasih, Syahruddin \& Japa, 2014), makes it easier for students to solve difficult problems (Oztruk \& Guven, 2016), and contributes to student achievement and knowledge development (Hodiyanto, 2017; Sappaile \& Djam'an, 2017; Diaz, Felmer, Randolph \& Gonzalez, 2017). The level of achievement of students taught by problem solving methods is different from conventional teaching methods (Behlol, Akbar \& Sehrish, 2018; Hu, Xing \& Tu, 2018).

\section{SCIENTIFIC APPROACH}

The implementation of scientific approaches in mathematics education includes observing, questioning, experimenting, associating, and communicating. The indicators, namely (1) observing include reading, listening, listening, and seeing, (2) questioning, including asking questions, answering questions, discussing information that has not been understood, clarifying additional information, (3) experimenting, including trying, demonstrating, imitating, reading other sources, collecting data from sources, and modifying, (4) associating, including processing information that has been collected, analyzed, connecting phenomena related to the discovery of a form, and concluding, and (5) communicating, including compiling reports about process, results, and conclusions (Permendikbud (81A), 2013; Hosman, 2014).

Whereas learning with a scientific approach influences the understanding of concepts (Syarifuddin, 2018; Tatik, 2014; Yuselis, Ismail \& Nery, 2015), increasing learning independence (Kamal, 2015), significantly influences learning outcomes (Ariawan, Darsana, \& Suardika, 2015; Untayana \& Harta, 2016; Wibowo, 2017), effectively influencing learning achievement, and student learning outcomes in good categories (In'am \& Hajar, 2017; Suhartati, 2016).

\section{HIGH ORDER THINKING SKILL}

In mathematics learning, high order thinking skills (HOTS) include several abilities, including communication, creativity, problem solving and mathematical reasoning (Brookhart, 2010; Madu, 2017; Setiawan, 2014; Tambunan, 2018; Wardhani, 2015). The importance of HOTS in learning mathematics is so that students have good abilities. Mathematical communication is an important condition for communicating various ideas into mathematical language (Baroody, 1993). Mathematical communication is needed in mathematics education, because it is the basis of mathematical solutions (Greenes, 1996), and mathematics as a means of communication of science (Armianti, 2009; Dan, 2013). Mathematical creativity is a person's activity to produce new things (Munandar, 1999; Solso, 1995), and a person's ability to choose mathematical 
Table 1. Research design

\begin{tabular}{ccc}
\hline Pretest & Treatment & Posttest \\
\hline $\mathrm{O}_{1}$ & Problem solving strategy & $\mathrm{O}_{2}$ \\
\hline $\mathrm{O}_{1}$ & Scientific approach & $\mathrm{O}_{2}$ \\
\hline
\end{tabular}

solutions (Sriraman, 2011). The aspects of mathematical creativity include flexibility, fluency, novelty, sensitivity, originality, elaboration (Evans, 1991; Munandar, 2012; Silver, 1997).

Problems in mathematics are story problems that are not clear certain rules that can be used to solve (Baroody, 1993; Hudoyo, 2005; James, 1976; Tambunan, 1999). Solving important problems in mathematics education, because problem solving is an effort to solve a problem to achieve a goal that cannot be achieved directly (Polya, 1973), a skill that involves the process of analysis, reasoning, prediction, evaluation and reflection (Anderson, 2009), and as a guide to solving a problem (Wena, 2011). Mathematics is a knowledge of logical reasoning (Soedjadi, 2000), and mathematics is formed as a result of reasoning (Rusffendi, 2006). Mathematical reasoning is a thought process to draw conclusions based on inductive and deductive (Sumantri, 2009). Reasoning is thought that produces a statement and reaches a conclusion on a problem solving (Lithner, 2008). The importance of reasoning in learning mathematics, because it can improve student learning outcomes (Setiadi, 2012).

\section{Research Questions}

1. Whether the problem solving strategy is more effective than the scientific approach to students' abilities in mathematical communication

2. Whether the problem solving strategy is more effective than the scientific approach to students' abilities in mathematical creativity

3. Whether the problem solving strategy is more effective than the scientific approach to students' abilities in problem solving

4. Whether the problem solving strategy is more effective than the scientific approach to students' abilities in mathematical reasoning

\section{Purpose of the Study}

The purpose of this study is to describe the effectiveness of problem solving strategy with the scientific approach on students' abilities in HOTS, namely communication, creativity, problem solving, and mathematical reasoning.

\section{METHOD}

This study uses quasi experiments, because in education it is not possible to do pure experimental research (Johnson \& Christenson, 2014). The experimental design used non-equivalent pretest-posttest control group design, the two treatment groups were given pretest, treatment, and posttest (Gay, 1987; Sugiyono, 2010). The experimental group is students taught by two partner teachers with problem-solving strategies (Polya, 1973), and the control group is students taught by two partner teachers with a scientific approach (Permendikbud (81A), 2013). The schematic representation of the research design is illustrated in Table 1.

The participants in this study were $10^{\text {th }}$ grade students from public and private high schools in MedanIndonesia, academic year 2018-2019 The number of participants in the experimental group, $\mathrm{n}=138$, and the control group, $\mathrm{n}=139$. Participants are in four classes, namely two classes from public schools and two private school classes taken by random sampling techniques (Arikunto, 2010; Sugiyono, 2011).

The research instrument used essay test which included communication, creativity, problem solving, and mathematical reasoning in system of linear equations material in the $10^{\text {th }}$ grade of high school. To guarantee the validity of the test instrument, it is validated by expert judgment techniques, and the reliability test used Cronbach's alpha formula, that is $\alpha=\left[\frac{N}{N-1}\right]\left[\frac{\sigma_{x-\sum_{i=1}^{N} \sigma_{y_{i}}^{2}}^{2}}{\sigma_{x}^{2}}\right]$, the instrument is reliable, if $\alpha \geq 0.70$ (Allen \& Yenn, 1979), As a result of the reliability test using statistical package for the social science (SPSS) version 21, Cronbach's Alpha values for mathematical communication, creativity, problem solving, and mathematical reasoning were $0.989,0.992,0.990$, and 0.969 respectively. 
Table 2. Descriptive statistics

\begin{tabular}{lllcccc}
\hline Mathematical Skills & Group & $\boldsymbol{N}$ & Minimum & Maximum & Mean & Std. Deviation \\
\hline \multirow{2}{*}{ Communication } & Experiment & 138 & 60.00 & 90.00 & 75.6304 & 5.73512 \\
\cline { 2 - 7 } Creativity & Control & 139 & 50.00 & 88.00 & 71.8705 & 9.97303 \\
\hline \multirow{2}{*}{ Problem solving } & Experiment & 138 & 60.00 & 90.00 & 75.6087 & 6.85452 \\
\cline { 2 - 7 } & Control & 139 & 50.00 & 88.00 & 70.4460 & 10.82213 \\
\hline \multirow{2}{*}{ Reasoning } & Experiment & 138 & 65.00 & 90.00 & 77.5435 & 5.52911 \\
\cline { 2 - 7 } & Control & 139 & 50.00 & 88.00 & 73.6259 & 9.44801 \\
\hline & Experiment & 138 & 60.00 & 96.00 & 77.7246 & 5.63198 \\
\hline
\end{tabular}

Table 3. Summary of ANOVA

\begin{tabular}{llcccc}
\hline Mathematical Skills & Group & Sum of Squares & Mean Square & $\boldsymbol{F}$ & Sig. \\
\multirow{2}{*}{ Communication } & Experiment & 678.675 & 169.669 & 5.896 & .000 \\
\cline { 2 - 6 } & Control & 3058.187 & 764.547 & 9.604 & .000 \\
\hline \multirow{2}{*}{ Creativity } & Experiment & 978.972 & 244.743 & 5.964 & .000 \\
\hline \multirow{2}{*}{ Problem solving } & Control & 87.611 & 903.135 & 9.063 & .000 \\
\hline \multirow{2}{*}{ Reasoning } & Experiment & 824.659 & 206.165 & 8.152 & .000 \\
\hline & Control & 1862.117 & 706.166 & 8.806 & .000 \\
\hline & Experiment & 743.295 & 247.765 & 9.217 & .000 \\
\cline { 2 - 7 } & Control & 3586.863 & 896.716 & 11.822 & .000 \\
\hline
\end{tabular}

Table 4. Summary of t test

\begin{tabular}{llcc}
\hline Mathematical Skills & Comparison Between Groups & $\boldsymbol{t}$-value & Sig. \\
\hline Communication & Experiment & 8.500 & .000 \\
\hline Creativity & Control & 11.743 & .000 \\
\hline Problem solving & Experiment & 11.447 & .000 \\
\hline Reasoning & Experiment & 11.754 & .000 \\
\hline
\end{tabular}

Hypothesis testing of this study using the $t$ test from the Bonferroni test, that is $t=\frac{\bar{x}_{1}-\bar{x}_{2}}{\sqrt{\left(\frac{S S \bar{x}_{1}+S S \bar{x}_{2}}{n_{1}+n_{2}-2}\right)\left(\frac{1}{n_{1}}+\frac{1}{n_{2}}\right)}}, \bar{x}$ is the average, $\mathrm{SS}$ is the sum of squares, $\mathrm{n}$ is the sample size. Test criteria, if $\mathrm{t} \geq t_{\left(0.025 ; n_{1}+n_{2}-2\right)}$, then the null hypothesis is rejected (Steven, 2002).

\section{RESULT}

Analysis of research data using SPSS version 21, the results are summarized in the Tables 2-4. Table 2 shows that for all mathematical skills, the average score of the experimental group is greater than the control group. Table 3 shows that for both groups, the pretest and posttest values were significantly linear. Table 4 shows the results of the $t$ test obtained from inter-group comparison testing of mathematical skills, and is used to answer the research hypothesis.

Hypothesis I: Problem solving strategies are more effective than scientific approaches to students' abilities in mathematical communication

The results of the $t$ test show that the value of $t=8.50$, Sig. $<0.025$, the null hypothesis was rejected, and therefore, problem solving strategies are more effective than scientific approaches to students' abilities in mathematical communication.

Hypothesis II: Problem solving strategies are more effective than scientific approaches to students' abilities in mathematical creativity

The results of the $t$ test show that the value of $t=11.743$, Sig. $<0.025$, the null hypothesis was rejected, and therefore, problem solving strategies are more effective than the scientific approach to students' abilities in mathematical creativity. 
Hypothesis III: Problem solving strategies are more effective than scientific approaches to students' abilities in solving mathematical problems.

The results of the $t$ test show that the value of $t=11.447$, Sig. $<0.025$, the null hypothesis was rejected, and therefore, problem solving strategies are more effective than the scientific approach to students' abilities in solving mathematical problems.

Hypothesis IV: Problem solving strategies are more effective than the scientific approach to students' abilities in mathematical reasoning.

The results of the $t$ test show that the value of $t=11.754$, Sig. $<0.025$, the null hypothesis was rejected, and therefore, problem solving strategies are more effective than the scientific approach to students' abilities in mathematical reasoning.

\section{DISCUSSION}

The results of this study indicate that problem solving strategies are more effective than the scientific approach to students' abilities in mathematical communication. These results are consistent with the results of a study by Lee (2017), that the problem solving strategy is better than other approaches. Solving problems with the Polya procedure is more effective than other approaches for building students' mathematical communication skills (Abdullah, Tarmizi \& Abu, 2010). Increasing students' mathematical communication skills through problem-based learning is better than conventional learning (Sari \& Rahadi, 2014). Problem solving strategies are more effective against students' mathematical creativity. This is consistent with the results of research that show that through problem solving can improve students' mathematical creativity skills (Ersoy \& Baser, 2014), students' mathematical creativity is better taught by problem solving methods than conventional approaches (Fadillah, 2016; Katminingsih \& Widodo, 2015), and there is a very strong influence on problem solving strategies for students' mathematical creativity (Tambunan, 2018).

Problem solving strategies are more effective than scientific approaches to students' ability to solve mathematical problems. These results are in accordance with the results of research that show that problem solving strategies with heuristics are effective against students' abilities in problem solving (Tambunan, 1999). The problem solving method by Polya (1973) can improve students' ability to solve problems (Cheng, She \& Huang, 2018; Komariyah, 2011; Selvianti, Ramdani \& Jusniar, 2013; Zulyadaini, 2017). It is also more effective against students' abilities in mathematical reasoning. This is consistent with the results of research that show that problem solving approaches contribute to critical, analytical, and reasoning skills (Cheng, She \& Huang, 2018; Goh, 2014; Lee \& Chen, 2015). Higher student reasoning abilities taught by problem solving models compared to conventional models (Muin, Hanifah \& Dwidian, 2018).

\section{CONCLUSION}

Many strategies can be used for problem solving in mathematics education. It has been tested, the effectiveness of problem solving strategy, and the scientific approach on students' mathematical abilities in HOTS. The results of this study concluded that problem solving strategies were more effective than scientific approaches to students' abilities in communication, creativity, problem solving, and mathematical reasoning. Therefore, so that students' mathematical abilities are better in HOTS, then problem solving strategy are better used compared to scientific approaches.

\section{Disclosure statement}

No potential conflict of interest was reported by the authors.

\section{Notes on contributors}

Hardi Tambunan - Nommensen HKBP University, Medan, Indonesia. 


\section{REFERENCES}

Abdullah, N. I., Tarmizi, R. A., \& Abu, R. (2010). The Effects of Problem Based Learning on Mathematics Performance and Affective Attributes in Learning Statistics at Form Four Secondary Level. Procedia Social and Behavioral Sciences, 8, 370-376. https://doi.org/10.1016/j.sbspro.2010.12.052

Abdullah, et al. (2017). Mathematics Teachers' Level of Knowledge and Practice on the Implementation of Higher Order Thinking Skill (HOTS). EURESIA Journal of Mathematics Science and Technology Education, 13(1), 3-17. https://doi.org/10.12973/euresia.2017.00601a

Ali, R., Hukamdad., Akhter, A., \& Khan. (2010). Effect of Using Problem Solving Method in Teaching Mathematics on the Achievement of Mathematics Students. Asian Social Science, 6(2), 67-72. Retrieved from https://pdfs.semanticscholar.org/d525/051a0d34723e43e6aef03d5bb1573bb6acfb.pdf

Al-Agili M. Z. G., Mamat, M. B., Abdullah, L., \& Maad, H. A. (2012). The Factors Influence Students' Achievement in Mathematics: A Case for Libyan's Students. World Applied Sciences Journal, 17(9), 1224-1230. Retrieved from https://pdfs.semanticscholar.org/a8ab/0e09da8190624db89ac91df1237912fd b8b9.pdf

Allen, M. J., \& Yen, W. M. (1979). Introduction to Measurement Theory. Monterey: Brooks /Cole Publishing company.

Anderson, J. (2009). Mathematics Curriculum Development and the Role of Problem Solving. ACSA Conference. Retrieved from http://acsa.edu.au/pages/images/judy\%20anderson\%20-\%20mathematics\% 20curriculum\%20development.pdf

Amalia, R. (2013). Penerapan Model Pembelajaran Pembuktian untuk Meningkatkan Kemampuan Berpikir Matematis Tingkat Tinggi Siswa SMA. Universitas Pendidikan Indonesia. http://repository.Upi.edu/1844/1/TMTK1104452_TITLE.pdf

Ariawan, E., Darsana, I. W., \& Suardika, W. R. (2015). Pengaruh Pendekatan Saintifik Terhadap Hasil Belajar Pengetahuan Matematika Tema Cita-Citaku Ditinjau dari Karakteristik Pertanyaan Guru Pada Siswa Kelas IV SD Negeri 27 Pemucutan. e-Journal PGSD Universitas Pendidikan Ganesha Jurusan PGSD, 3(1), 1-12. http://download.portalgaruda.org/article.php?article=346407\&val=1342\& title

Arikunto, S. (2010). Prosedur Penelitan. Suatu Pendekatan Praktik. Jakarta: Rineka Cipta.

Armianti. (2009). Komunikasi Matematika dan Kecerdasan Emosional. Prosiding Seminar Nasional Matematika dan Pendidikan Matematika Jurusan Pendidikan Matematika FMIPA UNY, 5, 270-280. http://eprints.uny.ac.id/7030/1/P16-Armiati.pdf

Baroody, A. J. (1993). Problem Solving. Reasoning, and Communicating K-8 (Helping Children Think Mathematically). New York: Macmillan Publishing Company.

Behlol, M. G., Akbar, R. A., \& Sehrish, H. (2018). Effectiveness of Problem Solving Method in Teaching Mathematics at Elementary Level. Bulletin of Education and Research, 40(1), 231-244. http://pu.edu.pk/images/journal/ier/PDF-FILES/17_40_1_18.pdf

Brookhart, S. M. (2010). How to Assess Higher-Order Thinking Skills in Your Classroom. Alexandria: ASCD.

Cheng, S. C., She, H. C., \& Huang, L. U. (2018). The Impact of Problem-Solving Instruction on Middle School Students' Physical Science Learning: Interplays of Knowledge, Reasoning, and Problem Solving. EURASIA Journal of Mathematics, Science and Technology Education, 14(3), 731-743. https://oi.org/10.12973/ejmste/80902

Dan, S. (2013). The Study On Mathematical Communication Competence and Its Assessment in China: The Preliminary Findings. East Normal University. Proceedings Ear come 6. Innovations and Exemplary Practices in Mathematics Education, 17-22.

Diaz, J. P., Felmer, P., Randolph, V., \& Gonzalez. (2017). Problem Solving as a Professional Development Strategy for Teachers: A Case Study with Fractions. Eurasia Journal of Mathematics Science and Technology Education, 13(3), 987-999. https://doi.org/10.12973/eurasia.2017.00653a

Effendy, M. (2018). Soal Ujian Nasional Sulit. Mendikbud.

Enu, J., Agyman, O. K., \& Nkum, D. (2015). Factors Influencing Students Mathematics Performance in Some Selected Colleges of Education in Ghana. International Journal of Education Learning and Development, 3(3), 68-74. http://www.eajournals.org/wp-content/uploads/Factors-Influencing-StudentsMathematics-Performance-In-Some-Selected-Colleges-Of-Education-In-Ghana.pdf 
Evans, J. R. (1991). Creative Thinking in the Decision and Management Scince. USA: South-Western Publishing Co.

Ersoy, E., \& Başerb, N. (2014). The Effects of Problem-Based Learning Method in Higher Education on Creative Thinking. Procedia-Social and Behavioral Sciences, 116(2014), 3494-3498 1877-0428. https://doi.org/10.1016/j.sbspro.2014.01.790

Fadillah, A. (2016). Pengaruh Pembelajaran Problem Solving Terhadap Kemampuan Berpikir Kreatif Matematika Siswa. Jurnal Pendidikan Matematika \& Matematika, 2(1), 1-8. https://www.researchgate.net/publication/321232596

Gay, L. R. (1987). Educational Research: Competencies for Analysis and Application, (3 ${ }^{\text {th }}$ ed). Columbus, Ohio: Merrill Corporation.

Goh, T. (2014). Students' Achievement, Skill and Confidence in Using Stepwise Problem Solving Strategies. Eurasia Journal of Mathematics, Science \& Technology Education, 10(6), 617-624. https://doi.org/10.12973/eurasia.2014.1223a

Greenes, C., \& Schulman, L. (1996). Communication Process in Mathematical Exploration and Investigation. In P.C Elliot and M.J Kenney (Ed). Communication in Mathematics, K-12 and Beyond. USA: NCTM.

Hodiyanto, H. (2017). Pengaruh Model Pembelajaran Problem Solving Terhadap Kemampuan Komunikasi Matematis Ditinjau dari Gender. Jurnal Riset Pendidikan Matematika, 4(2), 219-228. https://doi.org/10.21831/jrpm.v4i2.15770

Hosman. (2014). Pendekatan Saintifik dan Kontekstual dalam Pembelajaran Abad 21: Kunci Sukses Implementasi Kurikulum 2013. Bogor: Ghalia Indonesia.

Hu, Y., Xing, J., \& Tu, L. P. (2018). The Effect of a Problem-Opriented Teaching Method on University Mathematics Learning. EURASIA Journal of Mathematics, Science \& Technology Education, 14(5),1695-1703. https://doi.org/10.29333/ejmst/85108

Hudojo, H. (2005). Pengembangan Kurikulum dan Pembelajaran Matematika. Malang: UM Press.

James. G., James, R. C., \& Alchian, A. A. (1976). Mathematics Dictionary. New York: Van Nostrand Reinhold Co.

In'am, A., \& Hajar, S. (2017). Learning Geometry Through Discovery Learning Using a Scientific Approach. International Journal of Instruction, 10(1), 55-70. http://doi.org/10.12973/iji.2017.1014a

Jailani, J., Sugiman, S., \& Apino, E. (2017). Implementing the Problem-Based Learning in Order to Improve the Students' HOTS and Characters. Jurnal Riset Pendidikan Matematika, 4(2), 247-259. https://doi.org/10.21831/jrpm.v4i2.17674

James. G., James, R. C., \& Alchian, A. A. (1976). Mathematics Dictionary. New York: Van Nostrand Reinhold Co.

Johnson, R. B., \& Christensen, L. (2014). Education Research. Quantitatif, Qualitatif and Mixed Approaches. USA: SAGE Publications.

Kamal, S. (2015). Implementasi Pendekatan Saintific untuk Meningkatkan Kemandirian Belajar Matematika. Math Didactic: Jurnal Pendidikan Matematika, 1(1), 56-64. Retrieved from https://media.neliti.com/media/publications/176874-ID-implementasi-pendekatan-scientific-untuk.pdf

Katminingsih, Y., \& Widodo, S. (2015). Pengaruh Model Pembelajaran Berdasarkan Masalah Terhadap Kemampuan Berpikir Kreatif Matematis Siswa Ditinjau Menurut Gender SD Negeri Tarokan Kediri. Jurnal Math Educator Nusantara, 1(1), 77-89. Retrieved from http://download.portalgaruda.org/article.php?article=321371\&val=6717

Komariyah, K. (2011). Penerapan Metode Pembelajaran Problem Solving Model Polya untuk meningkatkan Kemampuan Memecahkan Masalah bagi Siswa Kelas IX di SMPN 13 Cimahi. Prosiding Seminar Nasional Penelitian, Pendidikan dan Penerapan MIPA. Fakultas MIPA, Universitas Negeri Yogyakarta. Retrieved from https://core.ac.uk/download/pdf/11064766.pdf

Lazarides, R., \& Ittel, A. (2012). Mathematics Interest and Achievement: What Role Do Perceived Parent and Teacher Support Play? A Longitudinal Analysis. International Journal of Gender, Science and Technology, 5(3), 208-231. Retrieved from http://genderandset.open.ac.uk/index.php/genderandset/ article/viewFile/301/526

Lee, C. I. (2017). An Appropriate Prompts System Based on the Polya Method for Mathematical Problem Solving. EURASIA Journal of Mathematics Science and Technology Education, 13(3), 893-910. https://doi.org/10.12973/eurasia.2017.00649a 
Lee, Y. C., \& Chen, M. J. (2015). Effects of Polya Questioning Instruction for Geometry Reasoning in Junior High School. Eurasia Journal of Mathematics, Science \& Technology Education, 11(6), 1547-1561. https://doi.org/10.12973/eurasia.2015.1419a

Liljedah, P., Trigo, M. S., Malaspina, U., \& Bruder, R. (2016). Problem Solving in Mathematics Education. Hamburg: Springer Open.

Lithner, J. (2008). A Research Framework for Creative and Imitative Reasoning. Education Studies in Mathematics, 67(3), 255-276.

Madu, A. (2017). Higher Order Tingking Skills (Hots) In Math Learning. IOSR Journal of Mathematics (IOSR$J M)$, 13(5), 70-75. Retrieved from http://www.iosrjournals.org/iosr-jm/papers/Vol13-issue5/Version2/L1305027075.pdf

Margaret, P. (2015). The Cause of the Low Mathematics Score in Indonesia. Retrieved from http://news.okezone.com/read/2014/09/09/3v3/1036506/ini-penyebab-nilai-matematika-indonesiarendah

Maurice, J. V., Dorfler, T., \& Artelt, C. (2014). The relation between interests and grades: Path analyses in primary school age. International Journal of Educational Research, 64, 1-11. https://doi.org/10.1016/j.ijer. 2013.09.011

Muin, A., Hanafiah, S. H., \& Dwidian, F. (2018). The Effect of Creative Problem Solving on Students' Mathematical Adaptive Reasoning. IOP Conf. Series: Journal of Physics: Conf. Series 948, 1-6. https://doi.org/10.1088/1742-6596/948/1/012001

Mulyati, T., Wahyudin., Herman, T., \& Mulyana, T. (2017). Effect of Integrating Children's Literature and SQRQCQ Problem Solving Learning on Elementary School Student's Mathematical Reading Comprehension Skill. International Electronic Journal of Mathematics Education, 12(3), 217-232. Retrieved from http://www.iejme.com/download/effect-of-integrating-childrens-literature-and-sqrqcqproblem-solving-learning-on-elementary-school.pdf

Munandar, U. (2012). Pengembangan Kreativitas Anak Berbakat. Jakarta: Rineka Cipta.

National Council of Teachers of Mathematics. (1989). Curriculum and Evaluation Standards for School Mathematics. Virginia, VA: NCTM.

National Council of Teachers of Mathematics. (2010). Why Is Teaching With Problem Solving Important to Student Learning?. Reston. VA: NCTM

Ozturk, T., \& Guven, B. (2016). Evaluating Students' Beliefs in Problem Solving Process: A Case Study. Eurasia Journal of Mathematics, Science \& Technology Education, 12(2), 411-429. https://doi.org/10.12973/eurasia.2016.1208a

Pehkonen, E. (2007). Problem Solving in Mathematics Education in Finland. Finlandia: University of Helsinki.

Permendikbud (54). (2013). Standar Kompetensi Lulusan Pendidikan Dasar dan Menengah.. Jakarta: Kemendikbud.

Permendikbud (81A). (2013). Standar Proses Pendidikan Dasar dan Menengah.. Jakarta: Kemendikbud.

Perveen, K. (2010). Effect Of The Problem Solving Approach on Academic Achievement of Students in Mathematics at the Secondary Level. Contemporary Issues In Education Research, 3(3), 9-14. Retrieved from https://files.eric.ed.gov/fulltext/EJ1072552.pdf

Pimta, S., Tayraukham, S., \& Nuangchalerm, P. (2009). Factors Influencing Mathematic Problem-Solving Ability of Sixth Grade Students. Journal of Social Sciences, 5(4), 381-385. Retrieved from https://files.eric.ed.gov/fulltext/ED506983.pdf

Polya, G. (1973). How To Solve It. New Jersey. Princeton.

Posmentier., \& Krulik. (2009). Problem Solving In Mathematics. USA: Corwin.

Ruseffendi, H. E. T. (2006). Pengantar Kepada Membantu Guru Mengembangkan Kompetensinya dalam Pengajaran Matematika untuk Meningkatkan CBSA. Bandung: Tarsito.

Sa'ad, T. U., Adamu, A., \& Sadiq, A. M. (2014). The Causes of Poor Performance in Mathematics among Public Senior Secondary School Students in Azare Metropolis of Bauchi State, Nigeria. Journal of Research \&Method in Education, 4(6), 32-40. https://doi.org/10.9790/7388-04633240

Sappaile, B. I., \& Djam'an, N. (2017). The Influence of Problem-Solving Methods on Students' Mathematics Learning Outcomes. Global Journal of Engineering Education, 19(3), 267-272. Retrieved from http://www.wiete.com.au/journals/GJEE/Publish/vol19no3/15-Sappaile-B.pdf 
Sari, L. S. P., \& Rahadi, M. (2014). Pembelajaran Berbasis Masalah untuk Meningkatkan Kemampuan Komunikasi Matematika Siswa Sekolah Menengah Pertama. Jurnal Pendidikan Matematika, 3(3), 143-150. Retrieved from https:/media.neliti.com/media/publications/226637-pembelajaran-berbasismasalah-untuk-meni.pdf

Selvianti., Ramdani., \& Jusniar. (2013). Efektivitas Metode Pemecahan Masalah untuk Meningkatkan Hasil Belajar dan Keterampilan Generik Sains Siswa Kelas XI IA 2 SMA Negeri 8 Makassar (Studi Pada Materi Pokok Hidrolisis Garam). Jurnal Chemica, 14(1), 55-65. Retrieved from http://download. portalgaruda.org/article.php?article=150249\&val=4338

Setiadi, et al. (2012). Kemampuan Matematika Siswa SMP Indonesia Menurut Benchmark Internasional TIMSS 2011. Jakarta: Kemendikbud.

Setiawan, H. (2014). Soal Matematika dalam PISA Kaitannya dengan Literasi Matematika dan Keterampilan Berpikir Tingkat Tinggi. Prosiding Seminar Nasional Matematika, Universitas Jember. Retrieved from https://jurnal.unej.ac.id/index.php/psmp/article/download/955/758

Silver, E. A. (1997). Fostering Creativity Through Instruction Rich in Mathematical Problem Solving and Thinking in Problem Posing. ZDM, 29(3), 45-62. Retrieved from http://www.fiz.karlsruhe.de/ fiz/publications/zdm

Sobel, M., \& Maletsky, E. M. (1988). Teaching Mathematics: A Sourcebook of Aids, Activities and Strategies. New Jersey: Englewood Cliffs.

Soedjadi, R. (2000). Kiat Pendidikan Matematika di Indonesia. Jakarta: Depdiknas.

Sriasih, N. W, Syahruddin., \& Japa, I.G.N (2014). Pengaruh Keterampilan Pemecahan Masalah Terhadap Hasil Belajar Matematika Siswa Kelas III SD Negeri 1 Banyuning. e-Journal Mimbar PGSD Universitas Pendidikan Ganesha Jurusan PGSD, 2(1), 1-10. Retrieved from http://download.portalgaruda.org/article.php?article=138723\&val

Sriraman, B. (2011). The Elements of Creativity and Giftedness in Mathematics. Rotterdam: Sense Publishers.

Stevens, J. (2002). Applied Multivariate Statistics for the Social Sciences $\left(4^{\text {th }}\right)$. London: Lawrence Erlbaum Associates Publisher.

Suastika, K. (2017). Mathematics Learning Model of Open Problem Solving to Develop Students' Creativity. International Electronic Journal of Mathematics Education, 12(3), 569-577. Retrieved from http://www.iejme.com/download/mathematics-learning-model-of-open-problem-solving-to-developstudents-creativity.pdf

Sugiyono. (2010). Metode Penelitian Kuantitatif, Kualitatif dan R\&D. Bandung: Alfabeta.

Sugiyono. (2011). Statistika untuk Penelitian. Bandung: Alfabeta.

Suhartati (2016). Penerapan Pendekatan Saintifik pada Materi Relasi dan Fungsi di Kelas X MAN 3 Banda Aceh. Jurnal Peluang, 4(2), 56-61.

Sukada, K., Sadia, W., \& Yudana, M. (2013). The Contribution of Learning Interest, Achievement Motivation and Mathematical Logic Intelligence to Students' Learning Outcomes at Sate Senior High School I Kintamani. e-Journal Program Pascasarjana Universitas Pendidikan Ganesha, 4, 1-11. Retrieved from http://download.portalgaruda.org/article.php?article=258746

Sumantri, J. S. (2009). Filsafat Ilmu, Jakarta Pustaka Sinar Harapan.

Sumantri, M. S., \& Whardani, P. A. (2017). Relationship between Motivation to Achieve and Professional Competence in the Performance of Elementary School Teachers. International Education Studies, 10(7), 118-125. https://oi.org/10.5539/ies.v10n7p118

Surifah, Mustiati, E., Syaifullah, M. Z., \& Bowo, A. N. A. (2016). The Influence of Motivation on Student Interest in Joining Accounting Profession Education. Jurnal Kependidikan, 46(2), 246-258. Retrieved from https://journal.uny.ac.id/index.php/jk/article/view/9615/pdf

Syarifuddin, S. (2018). The Effect of Using the Scientific Approach Through Concept Understanding and Critical Thinking in Science. Jurnal Prima Edukasia, 6(1), 21-31. https://doi.org/10.21831/jpe.v6i1.15312

Tambunan, H. (1999). Kemampuan Siswa Menyelesaikan Soal Cerita Pokok Bahasan Trigonometri dengan Strategi Heuristik. (Unpublished Master Thesis). IKIP Surabaya.

Tambunan, H. (2016). Mathematical Model for Mapping Students' Cognitive Capability. International Journal of Evaluation and Research in Education (IJERE), 5(3), 221 226. http://doi.org/10.11591/ijere.v513.4543 
Tambunan, H. (2018). Impact of Heuristic Strategy on Students' Mathematics Ability in High Order Thinking. International Electronic Journal of Mathematics Education, 13(3), 321-328. https://doi.org/10.12973/iejme/3928

Tambunan, H. (2018). The Dominant Factor of Teacher's Role as A Motivator of Students' Interest and Motivation in Mathematics Achievement. International Education Studies, 11(4), 114-151. https://doi.org/10.5539/ies.v11n4p144

Tambunan, H., \& Mawengkang, H. (2018). Integer Linear Programming Approach for Detection Learning Outcomes Achievement. Far East Journal of Mathematical Sciences (FJMS), 105(1), 95-109. https://doi.org/10.17654/MS105010095

Tanujaya, B., Mumu, J., \& Margono, G. (2017). The Relationship Between Higher Order Thinking Skills and Academic Performance of Student in Mathematics Instruction. International Education Studies, 10(11), 78-84. https://doi.org/10.5539/ies.v10n11p78

Tatik, P. (2014). Pendekatan Saintifik dan Penilaian Otentik. Yogyakarta: SPIRIT.

Turmudi. 2008. Landasan Filsafat dan Teori Pembelajaran Berparadigma Eksploratif dan Investigatif. Jakarta: PT Leuser Cita Pustaka.

Untayana, J., \& Harta, I. (2016). Pengembangan Perangkat Pembelajaran Limit Berbasis Pendekatan Saintifik Berorientasi Prestasi Belajar dan Kemampuan Komunikasi Matematika. Jurnal Riset Pendidikan Matematika, 3(1), 45-54. https://doi.org/10.2183/jrpm.v3i1.9683

Wardhani, S. (2015). Pembelajaran dan Penilaian Aspek Pemahaman Konsep, Penalaran dan Komunikasi, Pemecahan Masalah. Retrieved from http://p4tkmatematika.org/file/PRODUK/PAKETFASILITASI/SMP/Standar PenilaianPendidikan.pdf

Wena, M. (2011). Strategi Pembelajaran Inovatif Kontemporer. Jakarta: Bumi Aksara.

Wibowo, A. (2017). Pengaruh Pendekatan Pembelajaran Matematika Realistic dan Saintific Terhadap Prestasi Belajar, Kemampuan Penalaran Matematis dan Minat Belajar. Jurnal Riset Pendidikan Matematika, 4(1), 1-10. https://doi.org/10.21831/jrpm.v411.10066

Wibowo, T., Sutawidjaja, A., As'ari, A. R, \& Sulandra, I. M. (2017). Characteristics of Students Sensory Mathematical. Imagination in Solving Mathematics Problem. International Electronic Journal of Mathematics Education, 12(3), 609-619. Retrieved from http://www.iejme.com/download/ characteristics-of-students-sensory-mathematical-imagination-in-solving-mathematics-problem.pdf

Widodo, T., \& Kadarwati, S. (2013). High Order Thinking Berbasis Pemecahan Masalah Untuk Meningkatkan Hasil Belajar Berorientasi Pembentukan Karakter Siswa. Cakrawala Pendidikan, XXXII(1), 161-171.

Yazgan, Y. (2015). Sixth Graders and Non-Routine Problems: Which Strategies are Decisive for Success. Educational Research and Reviews, 10(13), 1807-1816. https://doi.org/10.5897/ERR2015.2230

Yuselis, Ismail, F., \& Nery, R. S. (2015). Pengaruh Pendekatan Saintifik Terhadap Pemahaman Konsep Siswa pada Pembelajaran Matematika di Kelas VII MTs Patra Mandiri Palembang. Jurnal Pendidikan Matematika JPM RAFA, 1(2), 258- 287.

Zulyadaini. (2017). Effects of Creative Problem Solving Learning Model on Mathematical Problem Solving Skills of Senior High School Students. IOSR Journal of Research \& Method in Education, 7(3), Ver. III, 33-37. https://doi.org/10.9790/7388-0703033337 